\title{
Do Stock Index Futures Affect Economic Growth? Evidence from 32 Countries
}

\author{
İlkay Şendeniz-Yüncü ${ }^{1}$, Levent Akdeniz ${ }^{2}$, and Kürşat Aydoğan ${ }^{2}$ \\ ${ }^{1}$ Department of Business Administration, Middle East Technical University, Ankara, Turkey; ${ }^{2}$ Faculty of \\ Business Administration, Bilkent University, Ankara, Turkey
}

\begin{abstract}
This article investigates the relationship between stock index futures markets development and economic growth using time-series methods for 32 developed and developing countries. Evidence of cointegration between stock index futures and real economy in 29 countries suggests the presence of co-movements among the variables, indicating long-run stationarity in those countries. Our findings show that there is Granger-causality from stock index futures markets development to economic growth for middle-income countries with relatively low real per capita GDP, and Granger-causality in the reverse direction for the countries with high real per capita GDP. Variance decomposition and impulse-response function (IRF) analyses results support the existence of a relationship between stock index futures and real economy.
\end{abstract}

KEY WORDS: economic growth, financial development, stock index futures

JEL CLASSIFICATION: G10, 016, 040

Several studies have shown that there is a positive relationship between a country's economic growth and development of its financial markets. ${ }^{1}$ It is intuitive that well-developed financial intermediaries in a country with well-functioning financial markets increase the efficiency with which a greater amount of capital accumulation is facilitated and a greater amount of funds is allocated to profitable investments. However, researchers have not yet thoroughly investigated the underlying mechanisms that suggest a positive relationship between the degree of development of the financial system and economic growth. For instance, does the development of derivative contracts contribute to economic growth?

One major function of financial markets is to reallocate risk between different economic agents. On the one hand, reallocation of risk enables borrowers to tailor their risk portfolios and therefore to achieve greater access to capital. On the other hand, savers become better able to diversify their risk and make more funds available for borrowing. As a result, an economy unquestionably gains from this efficient capital allocation generated from improved risk sharing. In a financial system, innovations such as derivatives are viewed as mechanisms to share risk and to allocate capital efficiently.

Derivatives markets are an integral part of a financial system. They allow markets to provide information about market clearing price, which is an essential component of an efficient economic system. In particular, futures markets widely distribute equilibrium prices that reflect demand and supply conditions, and knowledge of those prices is essential for investors, consumers, and producers to make informed decisions. As a result, investments become more productive and lead to a higher rate of economic growth. In addition, derivative instruments provide an opportunity for hedging risk, which in turn leads to economic growth.

Although - to the best of our knowledge - there is no study in the literature that directly links stock index futures markets to economic growth, there are studies that demonstrate the link between financial risk and economic growth. On the theoretical side, Acemoglu and Zilibotti (1997) show that reducing financial risk through holding diversified portfolios allows agents to invest in high-return

Address correspondence to İlkay Şendeniz-Yüncü, Middle East Technical University, Department of Business Administration, Universiteler Mahallesi Dumlupinar Bulvari No: 1, Cankaya, 06800 Ankara, Turkey. E-mail: sendeniz@metu.edu.tr 
projects with a positive influence on growth. Angeletos and Calvet (2006) illustrate that improvements in entrepreneurial risk sharing through the introduction of new hedging instruments will have a positive effect on savings and medium-run growth. Moreover, Turnovsky and Bianconi (2005) and Storesletten, Telmer, and Yaron (2004) show that idiosyncratic risks play an important role in aggregate risk; thus, reducing the idiosyncratic risks of economic agents leads to economic growth. Krebs (2002) also shows that a reduction in the variation in firm-specific risk decreases the ratio of physical to human capital and increases the total investment return and growth. ${ }^{2}$

On the empirical side, there are various studies that have investigated the relationship between financial development and economic growth. Goldsmith (1969) is one of the leaders of the view that financial intermediation contributes to economic growth, stating that there is a positive correlation between the sizes of financial systems and the supply and quality of financial services. Among many others, King and Levine (1993), Beck, Levine, and Loayza (2000), and Levine, Loayza, and Beck (2000) examine the relationship between financial intermediary development, namely banking sector development, and economic growth. ${ }^{3}$ Moreover, Atje and Jovanovic (1993), Demirgüç-Kunt and Levine (1996a, 1996b), Harris (1997), Levine and Zervos (1998), Rousseau and Wachtel (1998), and Arestis, Demetriades, and Luintel (2001) studied the relationship between stock market development and economic growth. Baier, Dwyer, and Tamura (2004) investigated the connection between the creation of stock exchanges and economic growth and documented an increase in economic growth after a stock exchange opens. Beck and Levine (2004) investigated the impact of both stock markets and banks on economic growth applying the generalized-method-of moments (GMM) techniques developed for dynamic panels. ${ }^{4}$ As a result of these studies, it is now a common belief that well-functioning financial intermediaries and markets ameliorate information and transaction costs to promote efficient resource allocation, and, hence, economic growth. However, researchers have not thoroughly examined the underlying mechanisms that lead to the positive relationship between the degree of development of the financial system and economic growth. Although the relationship between the banking sector, stock market, and economic growth has been extensively examined in the literature, the effect of the development of derivative markets on economic growth has not been examined thoroughly. For instance, is it only the banking sector or also the stock market within the financial system that contributes to economic growth? Does the development of derivatives markets contribute to economic growth as well? Our main contribution in this study is to investigate whether or not derivatives markets, more specifically the stock index futures markets, contribute to the economic growth. The answer to this question has important policy implications because clarifying the role of stock index futures in economic growth may lead governments to support developing their derivatives markets in order to promote economic growth.

Haiss and Sammer (2010) applied the Merton and Bodie (1995) functional framework in the discussion of the spheres of derivatives' influence in the finance-growth nexus. They examined the impact of derivatives markets on asset management and the economy through three transmission channels: (1) the volume channel, (2) the efficiency channel, and (3) the risk channel. In their study, Haiss and Sammer (2010) tried to answer the question whether the growing importance of derivatives changed the financial sectors' ability to support economic growth and development in the US. The authors found only a weak correlation of the financial sector and derivatives in particular with economic growth and suggested further research on the subject. ${ }^{5}$

In our study, we use the time-series approach to examine the relationship between stock index futures markets development and economic growth in 32 developed and developing countries. We try to answer the question whether the developments in stock index futures markets contribute to economic growth. We also try to find the direction of the causal link between stock index futures and the economy. As Lin, Sun, and Jiang (2009) mention, governments are active in the process of emergence and development of appropriate financial institutional arrangements. They argue that the efficient operation of financial institutions requires a well-functioning legal system, wise regulations, and suitable supervision, which are all responsibilities of the government. In their article, Lin, Sun, and Jiang (2009) propose a hypothesis that the optimal financial structure in an economy depends on its stage of economic development. A financial structure is optimal for a country at some stage of 
economic development only when the characteristics of the financial structure match the characteristics of the optimal industrial structure determined by the endowment structure in the economy. On the other hand, developing countries have been advised to develop financial systems similar to the model in advanced economies. However, the optimal financial structure for less-developed countries is likely to be systemically different from that for advanced economies, and imitating the financial model of advanced economies will not generate better economic performance in those countries.

Especially in emerging markets, most of the production takes place in privately held small firms where risk sharing is absent most of the time. ${ }^{6}$ Thus, promoting financial markets and services that ease risk sharing in these countries may result in welfare increase.

Our findings show that there is unidirectional Granger-causality from stock index futures markets development to economic growth in seven countries, most of which are middle-income countries and have relatively low real per capita GDP levels, while this relationship is the reverse for 15 high per capita income countries. Our findings are intuitive in the following sense. Futures markets widely distribute equilibrium prices that reflect demand and supply conditions, and knowledge of those prices allows investors, consumers, and producers to make informed decisions. Consequently, the amelioration of information and transaction costs fosters efficient resource allocation, thus leading to economic growth. Middle-income economies benefit more from the increase in the efficiency of resource allocation. Our findings have important policy implications. Government policies to promote derivative markets may help lead to a higher economic growth, especially for middle-income countries.

\section{Data}

We perform time-series analyses to examine the relationship between stock index futures markets development and economic growth for 32 developed and developing countries. As a proxy for the "stock index futures" variable (hereafter FUTURES), we use the total value of quarterly stock index futures contracts to quarterly seasonally adjusted nominal Gross Domestic Product ratio for each country. We obtain the total value of stock index futures contracts by multiplying the volume of contracts traded by the contract prices in each period. Since futures markets are relatively new markets among other financial instruments, there is the issue of data limitations. As data source we used Datastream. The 32 countries in our sample are all the countries that have stock index futures data in Datastream. Again due to data limitations, we preferred to use stock index futures data rather than other futures markets data. In this respect we refer to Kenourgios, Samitas, and Drosos (2008), who show that stock index futures contract is an effective tool for hedging risk by using the S\&P 500 stock index futures data in their study.

"Real economy" (hereafter RGDPC) is measured by the logarithm of quarterly seasonally adjusted real per capita GDP. Index futures values and GDP data are in the countries' national currencies. Our source for the GDP data is also Datastream.

For the time-series analyses, we use quarterly data for different time periods for 32 countries. $^{7}$ The longest data period is 1982:Q3-2015:Q4 for the United States. We present the names of the countries, futures exchanges, and time periods for each country in Table 1. Descriptive statistics by country are presented in Table 2 .

\section{Time-Series Analyses}

To examine the relationship between stock index futures markets development and economic growth for individual countries through time, we run the following time-series tests using quarterly data: unit root tests to see whether the series are stationary or not, cointegration tests to see the co-movement of variables in the long run, and to select a vector error correction model (VECM), causality tests to analyze the direction of causalities, variance decompositions to break down the variance of the forecast error for each variable into components, and impulse-response function (IRF) analysis to trace the 
Table 1. Countries, futures exchanges, and time periods.

\begin{tabular}{|c|c|c|c|c|}
\hline Market & WB income group & Index name & Exchange & Period \\
\hline Australia & High income & SPI 200 INDEX & $\begin{array}{l}\text { Sydney Futures Exchange } \\
\text { (SFE) }\end{array}$ & 2000Q3-2015Q4 \\
\hline Austria & High income & ATX INDEX & Vienna Stock Exchange & 1992Q4-2014Q1 \\
\hline Belgium & High income & BEL20 INDEX & Euronext.liffe Brussels & 1994Q1-2015Q4 \\
\hline Brazil & $\begin{array}{l}\text { Upper middle } \\
\text { income }\end{array}$ & BOVESPA INDEX & $\begin{array}{l}\text { Bolsa de Mercadorias \& } \\
\text { Futuros }\end{array}$ & 1986Q2-2015Q4 \\
\hline Canada & High income & S\&P/TSX 60 INDEX & Montreal Exchange & 1999Q4-2015Q4 \\
\hline China & $\begin{array}{l}\text { Upper middle } \\
\text { income }\end{array}$ & CSI 300 INDEX & $\begin{array}{l}\text { China Financial Futures } \\
\text { Exchange }\end{array}$ & 2010Q3-2015Q4 \\
\hline Denmark & High income & $\begin{array}{l}\text { OMXC20 CAP } \\
\text { INDEX }\end{array}$ & Nordic Exchange & 2012Q1-2015Q4 \\
\hline France & High income & CAC 40 INDEX & Euronext.liffe Paris & 1999Q2-2015Q4 \\
\hline Germany & High income & DAX INDEX & EUREX & 1991Q1-2015Q4 \\
\hline Greece & High income & FTSE/ASE-20 & Athens Derivatives Exchange & 1999Q4-2015Q4 \\
\hline Hong Kong, China & High income & HANG SENG INDEX & Hong Kong Futures Exchange & 1986Q3-2015Q4 \\
\hline Hungary & High income & BUX INDEX & Budapest Stock Exchange & 1995Q2-2015Q4 \\
\hline India & $\begin{array}{l}\text { Lower middle } \\
\text { income }\end{array}$ & S\&P CNX NIFTY & National India & 2000Q3-2015Q4 \\
\hline Italy & High income & FTSE MIB INDEX & Italian Derivatives Market & 2004Q2-2015Q4 \\
\hline Japan & High income & NIKKEI 225 INDEX & Osaka Securities Exchange & 1988Q4-2015Q4 \\
\hline Korea, Rep. & High income & KOSPI 200 INDEX & $\begin{array}{l}\text { Korea Futures Exchange } \\
\text { (KOFEX) }\end{array}$ & 1996Q1-2015Q4 \\
\hline Malaysia & $\begin{array}{l}\text { Upper middle } \\
\text { income }\end{array}$ & $\mathrm{KLCl}$ & Kuala Lumpur & 2000Q1-2015Q4 \\
\hline Mexico & $\begin{array}{l}\text { Upper middle } \\
\text { income }\end{array}$ & IPC INDEX & Mexican Derivatives Exchange & 1999Q3-2015Q4 \\
\hline The Netherlands & High income & AEX II & Euronext.liffe Amsterdam & 1989Q1-2015Q4 \\
\hline Norway & High income & OBX INDEX & Oslo Stock Exchange & 1992Q4-2015Q4 \\
\hline Poland & High income & WIG 40 & Warsaw Stock Exchange & 2007Q2-2015Q4 \\
\hline Portugal & High income & PSI 20 INDEX & Euronext.liffe Lisbon & 1996Q3-2015Q4 \\
\hline Russian Federation & $\begin{array}{l}\text { Upper middle } \\
\text { income }\end{array}$ & RTS INDEX & Russian Trading System & 2005Q4-2015Q4 \\
\hline Singapore & High income & $\begin{array}{l}\text { MSCI SINGAPORE } \\
\text { INDEX }\end{array}$ & $\begin{array}{l}\text { Singapore } \\
\text { Exchange-Derivatives } \\
\text { Trading Division }\end{array}$ & 1998Q4-2015Q4 \\
\hline South Africa & $\begin{array}{l}\text { Upper middle } \\
\text { income }\end{array}$ & $\begin{array}{l}\text { ALL SHARE } 40 \\
\text { INDEX }\end{array}$ & $\begin{array}{l}\text { South African Futures } \\
\text { Exchange }\end{array}$ & 1990Q3-2015Q4 \\
\hline Spain & High income & $\begin{array}{l}\text { IBEX } 35 \text { PLUS } \\
\text { INDEX }\end{array}$ & MEFF Renta Variable & 1992Q3-2015Q4 \\
\hline Sweden & High $\mathrm{i}$ & OMXS30 INDEX & OM Nordic Exchange & 2005Q2-2015Q4 \\
\hline Switzerland & High income & SMI INDEX & EUREX & 1991Q1-2015Q4 \\
\hline Thailand & $\begin{array}{l}\text { Lower middle } \\
\text { income }\end{array}$ & MINI SET50 INDEX & Thailand Futures Exchange & 2006Q3-2015Q4 \\
\hline Turkey & $\begin{array}{l}\text { Upper middle } \\
\text { income }\end{array}$ & ISE 30 & Turkish Derivatives Exchange & 2005Q2-2015Q4 \\
\hline United Kingdom & High income & FTSE 100 INDEX & Euronext.liffe London & 1984Q3-2015Q4 \\
\hline United States & High income & S\&P 500 INDEX & Chicago Mercantile Exchange & 1982Q3-2015Q4 \\
\hline
\end{tabular}

effect of a one-time shock to one of the endogenous variables on the current and future values of itself and the other endogenous variables. 
Table 2. Descriptive statistics.

\begin{tabular}{|c|c|c|c|c|c|c|c|c|c|c|}
\hline \multirow[b]{2}{*}{ Country } & \multicolumn{5}{|c|}{ FUTURES } & \multicolumn{5}{|c|}{ RGDPC } \\
\hline & Obs. & Mean & St. dev. & Min. & Max. & Obs. & Mean & St. dev. & Min. & Max. \\
\hline Australia & 61 & 0.680 & 0.268 & 0.001 & 1.287 & 132 & 9.480 & 0.192 & 9.128 & 9.751 \\
\hline Austria & 73 & 0.019 & 0.012 & 0.002 & 0.053 & 76 & 9.025 & 0.081 & 8.845 & 9.118 \\
\hline Belgium & 83 & 0.041 & 0.033 & 0.001 & 0.113 & 80 & 9.022 & 0.079 & 8.852 & 9.113 \\
\hline Brazil & 82 & 0.175 & 0.129 & 0.028 & 0.589 & 76 & 7.135 & 0.115 & 6.991 & 7.323 \\
\hline Canada & 64 & 0.249 & 0.124 & 0.013 & 0.447 & 132 & 9.216 & 0.147 & 8.928 & 9.428 \\
\hline China & 21 & 0.226 & 0.197 & 0.072 & 0.792 & 16 & 11.429 & 0.134 & 11.175 & 11.674 \\
\hline Denmark & 15 & 0.010 & 0.004 & 0.000 & 0.016 & 80 & 11.280 & & 11.142 & 11.373 \\
\hline France & 66 & 0.753 & 0.202 & 0.471 & 1.442 & 132 & & & & 8.980 \\
\hline Germany & 99 & 1.365 & 1.127 & 0.0 & & 96 & & & & 9.050 \\
\hline Greece & 64 & 0.063 & & 0.0 & 0.1 & 80 & & & & 8.645 \\
\hline Hong Kong, China & 117 & 0.005 & & 0.000 & 0.0 & 132 & 17.671 & & & 18.207 \\
\hline Hungary & 81 & 0.010 & & 0.000 & & 80 & 13.123 & & 12.844 & 13.306 \\
\hline India & 61 & 0.479 & 0.359 & 0.0 & & 75 & & & & 9.937 \\
\hline Italy & 46 & & 0. & & & 80 & & & & 8.890 \\
\hline Japan & 87 & 0.380 & 0.2 & 0.142 & 0.9 & 84 & 13.782 & & 13. & 13.865 \\
\hline Korea, & 77 & 3.559 & 2.3 & 0.0 & 9.083 & 132 & 15.090 & 24 & 13.977 & 15.779 \\
\hline Malaysia & 23 & 0.000 & 0.000 & 0.000 & 0.000 & 20 & 15.882 & 54 & 15.799 & 15.973 \\
\hline Mexico & 65 & 0.015 & 0.012 & 0.000 & 0.034 & 88 & 10.128 & 0.071 & 9.952 & 10.230 \\
\hline The Neth & 83 & 1.056 & 0.502 & 0.232 & 2.484 & 76 & 9.102 & 0.076 & 8.905 & 9.200 \\
\hline Norway & 92 & 0.038 & 0.031 & 0.000 & 0.114 & 132 & 11.738 & 0.196 & 11.338 & 11.977 \\
\hline Poland & 34 & 0.001 & 0.001 & 0.000 & 0.003 & 80 & 8.867 & 0.300 & 8.314 & 9.283 \\
\hline Portugal & 77 & 0.028 & 0.049 & 0.001 & 0.218 & 80 & 8.297 & 0.063 & 8.123 & 8.376 \\
\hline Russian $\mathrm{Fe}$ & 39 & 14.201 & 9.482 & 0.533 & 34.428 & 48 & 11.102 & 0.135 & 10.802 & 11.246 \\
\hline Singapore & 68 & 0.000 & 0.000 & 0.000 & 0.001 & 132 & 16.129 & 0.383 & 15.416 & 16.684 \\
\hline South Afric & 101 & 0.760 & 0.597 & 0.021 & 2.344 & 132 & 9.400 & 0.088 & 9.271 & 9.555 \\
\hline Spain & 83 & 0.811 & 0.564 & 0.250 & 2.968 & 80 & 8.614 & 0.090 & 8.407 & 8.734 \\
\hline Sweden & 42 & 0.936 & 0.242 & 0.202 & 1.612 & 88 & 11.379 & 0.139 & 11.102 & 11.540 \\
\hline Switzerland & 99 & 0.849 & 0.629 & 0.004 & 2.597 & 132 & 9.744 & 0.103 & 9.536 & 9.900 \\
\hline Thailand & 37 & 0.000 & 0.000 & 0.000 & 0.000 & 88 & 17.038 & 0.191 & 16.708 & 17.359 \\
\hline Turkey & 41 & 0.206 & 0.127 & 0.000 & 0.409 & 68 & 5.807 & 0.155 & 5.561 & 6.037 \\
\hline United K & 125 & 0.542 & 0.465 & 0.002 & 1.580 & 132 & 8.590 & 0.193 & 8.189 & 8.836 \\
\hline United States & 133 & 0.316 & 0.233 & 0.013 & 1.014 & 132 & 10.609 & 0.172 & 10.241 & 10.833 \\
\hline
\end{tabular}

Notes: FUTURES: Total value of quarterly stock index futures contracts to quarterly seasonally adjusted nominal GDP ratio, RGDPC: Logarithm of quarterly seasonally adjusted real per capita GDP.

\section{Unit Root Tests}

The existence of a stationary linear combination between nonstationary series suggests the existence of a cointegrating relationship between them. Therefore, stationarity of the series should be tested. We use the Augmented-Dickey-Fuller (ADF) and Phillips-Perron (PP) unit root tests to determine the stationarity of FUTURES and RGDPC. Both tests have the null hypothesis of existence of a unit root, rejection of which indicates stationarity. We choose lags that minimize the Akaike Information Criterion (AIC) for the ADF test. The Newey-West bandwidth automatic selection is used for the PP unit root test. Both ADF and PP tests fail to reject the null hypothesis of unit root for 31 countries in level series, indicating non-stationarity (except for Sweden). Both ADF and PP tests reject the null hypothesis for 31 countries in first differenced series, indicating stationarity (except for Spain). For Sweden and Spain there is inconsistency between the two tests. Therefore, we run a third unit root test, the Kwiatkowski-Phillips-Schmidt-Shin (KPSS) test, for the series that showed inconsistency between the ADF and PP tests for those two countries. The KPSS test 
results confirmed non-stationarity of the level series and stationarity of the first differenced series for Sweden and Spain. ${ }^{8}$ Table 3 presents the results of the ADF and PP unit root tests for 32 countries in levels and first differences.

\section{Cointegration Tests}

Although individual series are nonstationary, a linear combination of these series may be stationary. We run Johansen's cointegration tests (Trace test) to determine whether the nonstationary series FUTURES and RGDPC move together over time and whether cointegration exists among them. Table 4 presents the results of the Johansen cointegration tests, which has a null hypothesis of "no cointegration". Rejection of the null hypothesis indicates the existence of at least one cointegrating equation. Evidence of cointegration between FUTURES and RGDPC for 29 countries (except for Germany, Switzerland, and the United States) suggests the presence of co-movements among the stock index futures and the real economy in those countries, indicating long-run stationarity between the two variables.

\section{Causality Tests}

We perform Granger Causality/Block Exogeneity Wald Tests to see the direction of a causal link between stock index futures markets development and economic growth. Our regressions are as follows:

$$
\begin{gathered}
\triangle R G D P C_{t}=\sum_{i=1}^{n} \pi_{11} \Delta R G D P C_{t-i}+\sum_{i=1}^{n} \pi_{12} \Delta F U T U R E S_{t-i}+u_{t} \\
\triangle F U T U R E S_{t}=\sum_{i=1}^{n} \pi_{22} \Delta F U T U R E S_{t-i}+\sum_{i=1}^{n} \pi_{21} \Delta R G D P C_{t-i}+v_{t}
\end{gathered}
$$

where $\Delta$ is the change operator, and $u$ and $v$ are the error terms. For the right-hand side of the above equations, we try lags between 1 and 12 and choose the lag that gives the lowest value of AIC. The null hypotheses are that change in FUTURES does not Granger-cause change in RGDPC, in the first regression, and that change in RGDPC does not Granger-cause change in FUTURES in the second regression. Table 5 presents the results of Granger Causality/Block Exogeneity Wald Tests. Our results show unidirectional Granger-causality between stock index futures and real economy in 22 countries. We observe significant causality from $\triangle$ FUTURES to $\triangle$ RGDPC in Australia, Brazil, China, Hungary, India, Mexico, and South Africa, most of which have relatively low real per capita GDP levels among the countries in our sample. For example, in Hungary, stock index futures market started its operation in the second quarter of 1995 and has grown significantly since then. In the first years of its operation, especially in 1995, 1996, and 1997, the stock index futures market in Hungary experienced an enormous growth as a percentage of GDP; afterward, on an average, it grew by $28.5 \%$ between 1998 and 2014 . While GDP grew by $0.2 \%$ and gross fixed capital formation grew by $1.9 \%$ between 1992 and 1995, after stock index futures market started its operation in Hungary, GDP grew by 2.2\% and gross fixed capital formation grew by 3.3\% between 1996 and 2014. Futures market allowed for greater and more efficient risk sharing, thereby making it possible for firms to undertake relatively riskier projects and promoted economic growth.

We observe unidirectional Granger-causality in the reverse direction, i.e. from $\triangle$ RGDPC to $\triangle$ FUTURES, in Austria, France, Germany, Greece, Hong Kong-China, Italy, Japan, the Netherlands, Poland, Portugal, Singapore, Spain, Sweden, Switzerland, and the United Kingdom, which have high real per capita GDP levels. The bidirectional causality in Belgium and Norway suggests the interdependence of futures market development and economic growth $(\triangle \mathrm{RGDPC} \Leftrightarrow \Delta \mathrm{FUTURES})$ in these two countries. 
Table 3. Unit root tests.

\begin{tabular}{|c|c|c|c|c|c|c|}
\hline \multirow[b]{2}{*}{ Country } & & \multirow[b]{2}{*}{ Test } & \multirow{2}{*}{$\frac{\text { FUTURES }}{\text { t-stat. }}$} & \multirow[b]{2}{*}{$p$-value } & \multirow{2}{*}{$\frac{\text { RGDPC }}{\text { t-stat. }}$} & \multirow[b]{2}{*}{$p$-value } \\
\hline & & & & & & \\
\hline \multirow[t]{4}{*}{ Australia } & Level & ADF & -2.406 & 0.373 & -1.562 & 0.803 \\
\hline & & PP & -2.366 & 0.393 & -1.373 & 0.864 \\
\hline & F. D. $(\Delta)$ & ADF & -8.630 & 0.000 & -6.079 & 0.000 \\
\hline & & PP & -8.615 & 0.000 & -8.494 & 0.000 \\
\hline \multirow[t]{4}{*}{ Austria } & Level & ADF & -1.693 & 0.749 & -2.659 & 0.256 \\
\hline & & PP & -1.555 & 0.806 & -1.592 & 0.791 \\
\hline & F. D. $(\Delta)$ & ADF & -4.091 & 0.008 & -5.147 & 0.000 \\
\hline & & $\mathrm{PP}$ & -11.776 & 0.000 & -7.211 & 0.000 \\
\hline \multirow[t]{4}{*}{ Belgium } & Level & $A D F$ & -2.556 & 0.107 & -1.128 & 0.917 \\
\hline & & $\mathrm{PP}$ & -1.475 & 0.541 & -0.993 & 0.939 \\
\hline & F. D. $(\Delta)$ & $A D F$ & -2.728 & 0.074 & -4.383 & 0.004 \\
\hline & & $\mathrm{PP}$ & -9.184 & 0.000 & -4.059 & 0.011 \\
\hline \multirow{4}{*}{ Brazil } & Level & $A D F$ & -2.511 & 0.322 & -2.161 & 0.503 \\
\hline & & $\mathrm{PP}$ & -2.152 & 0.509 & -2.125 & 0.523 \\
\hline & F. D. $(\Delta)$ & $A D F$ & -5.752 & 0.000 & -4.915 & 0.001 \\
\hline & & $\mathrm{PP}$ & -5.715 & 0.000 & -7.444 & 0.000 \\
\hline \multirow[t]{4}{*}{ Canada } & Level & $A D F$ & -1.561 & 0.497 & -1.348 & 0.606 \\
\hline & & $\mathrm{PP}$ & -1.583 & 0.485 & -0.903 & 0.785 \\
\hline & F. D. $(\Delta)$ & ADF & -3.247 & 0.022 & -6.689 & 0.000 \\
\hline & & PP & -7.947 & 0.000 & -6.600 & 0.000 \\
\hline \multirow[t]{4}{*}{ China } & Level & ADF & -1.693 & 0.749 & -2.659 & 0.256 \\
\hline & & $\mathrm{PP}$ & -1.555 & 0.806 & -1.592 & 0.791 \\
\hline & F. D. $(\Delta)$ & ADF & -4.091 & 0.008 & -5.147 & 0.000 \\
\hline & & $\mathrm{PP}$ & -11.776 & 0.000 & -7.211 & 0.000 \\
\hline \multirow[t]{4}{*}{ Denmark } & Level & ADF & -1.693 & 0.749 & -2.659 & 0.256 \\
\hline & & PP & -1.555 & 0.806 & -1.592 & 0.791 \\
\hline & F. D. $(\Delta)$ & ADF & -4.091 & 0.008 & -5.147 & 0.000 \\
\hline & & PP & -11.776 & 0.000 & -7.211 & 0.000 \\
\hline \multirow[t]{4}{*}{ France } & Level & ADF & -2.431 & 0.361 & -1.051 & 0.932 \\
\hline & & $\mathrm{PP}$ & -2.370 & 0.392 & -0.655 & 0.974 \\
\hline & F. D. $(\Delta)$ & ADF & -9.137 & 0.000 & -5.590 & 0.000 \\
\hline & & $\mathrm{PP}$ & -9.135 & 0.000 & -5.595 & 0.000 \\
\hline \multirow[t]{4}{*}{ Germany } & Level & ADF & -1.302 & 0.626 & -0.271 & 0.924 \\
\hline & & PP & -1.222 & 0.663 & -0.054 & 0.951 \\
\hline & F. D. $(\Delta)$ & ADF & -10.674 & 0.000 & -7.063 & 0.000 \\
\hline & & $\mathrm{PP}$ & -10.704 & 0.000 & -7.054 & 0.000 \\
\hline \multirow[t]{4}{*}{ Greece } & Level & $A D F$ & -1.693 & 0.749 & -2.659 & 0.256 \\
\hline & & $\mathrm{PP}$ & -1.555 & 0.806 & -1.592 & 0.791 \\
\hline & F. D. $(\Delta)$ & $A D F$ & -4.091 & 0.008 & -5.147 & 0.000 \\
\hline & & $\mathrm{PP}$ & -11.776 & 0.000 & -7.211 & 0.000 \\
\hline \multirow{4}{*}{ Hong Kong, China } & Level & ADF & -0.734 & 0.833 & -1.403 & 0.579 \\
\hline & & PP & -0.955 & 0.767 & -1.286 & 0.635 \\
\hline & F. D. $(\Delta)$ & ADF & -6.346 & 0.000 & -2.642 & 0.088 \\
\hline & & $\mathrm{PP}$ & -11.066 & 0.000 & -14.047 & 0.000 \\
\hline \multirow[t]{4}{*}{ Hungary } & Level & $A D F$ & -2.042 & 0.569 & -1.275 & 0.887 \\
\hline & & $\mathrm{PP}$ & -2.251 & 0.455 & -0.887 & 0.952 \\
\hline & F. D. $(\Delta)$ & $A D F$ & -4.992 & 0.001 & -4.578 & 0.002 \\
\hline & & $\mathrm{PP}$ & -9.236 & 0.000 & -4.534 & 0.003 \\
\hline
\end{tabular}


Table 3. Unit root tests. (Continued)

\begin{tabular}{|c|c|c|c|c|c|c|}
\hline \multirow[b]{2}{*}{ Country } & & \multirow[b]{2}{*}{ Test } & \multirow{2}{*}{$\frac{\text { FUTURES }}{\text { t-stat. }}$} & \multirow[b]{2}{*}{$p$-value } & \multirow{2}{*}{$\frac{\text { RGDPC }}{\text { t-stat. }}$} & \multirow[b]{2}{*}{$p$-value } \\
\hline & & & & & & \\
\hline \multirow[t]{4}{*}{ India } & Level & ADF & -1.075 & 0.924 & -2.516 & 0.320 \\
\hline & & PP & -1.297 & 0.879 & -2.528 & 0.314 \\
\hline & F. D. $(\Delta)$ & ADF & -4.701 & 0.002 & -8.592 & 0.000 \\
\hline & & PP & -7.435 & 0.000 & -8.592 & 0.000 \\
\hline \multirow[t]{4}{*}{ Italy } & Level & ADF & -2.128 & 0.235 & -1.520 & 0.518 \\
\hline & & PP & -2.171 & 0.219 & -1.418 & 0.569 \\
\hline & F. D. $(\Delta)$ & ADF & -5.725 & 0.000 & -4.108 & 0.002 \\
\hline & & $\mathrm{PP}$ & -5.725 & 0.000 & -4.122 & 0.002 \\
\hline \multirow[t]{4}{*}{ Japan } & Level & $A D F$ & -2.076 & 0.255 & -1.708 & 0.424 \\
\hline & & $\mathrm{PP}$ & -1.987 & 0.292 & -1.261 & 0.644 \\
\hline & F. D. $(\Delta)$ & $A D F$ & -9.989 & 0.000 & -7.646 & 0.000 \\
\hline & & $\mathrm{PP}$ & -10.196 & 0.000 & -7.659 & 0.000 \\
\hline \multirow[t]{4}{*}{ Korea, Rep. } & Level & ADF & -0.834 & 0.957 & -1.334 & 0.875 \\
\hline & & PP & -0.705 & 0.969 & -1.355 & 0.869 \\
\hline & F. D. $(\Delta)$ & $A D F$ & -9.686 & 0.000 & -10.279 & 0.000 \\
\hline & & PP & -9.680 & 0.000 & -10.277 & 0.000 \\
\hline \multirow[t]{4}{*}{ Malaysia } & Level & $A D F$ & -1.693 & 0.749 & -2.659 & 0.256 \\
\hline & & $\mathrm{PP}$ & -1.555 & 0.806 & -1.592 & 0.791 \\
\hline & F. D. $(\Delta)$ & $A D F$ & -4.091 & 0.008 & -5.147 & 0.000 \\
\hline & & $\mathrm{PP}$ & -11.776 & 0.000 & -7.211 & 0.000 \\
\hline \multirow[t]{4}{*}{ Mexico } & Level & $A D F$ & -1.217 & 0.662 & -1.455 & 0.552 \\
\hline & & PP & -1.092 & 0.714 & -1.085 & 0.719 \\
\hline & F. D. $(\Delta)$ & ADF & -4.871 & 0.000 & -5.694 & 0.000 \\
\hline & & PP & -10.142 & 0.000 & -5.331 & 0.000 \\
\hline \multirow[t]{4}{*}{ The Netherlands } & Level & ADF & -1.693 & 0.749 & -2.659 & 0.256 \\
\hline & & PP & -1.555 & 0.806 & -1.592 & 0.791 \\
\hline & F. D. $(\Delta)$ & ADF & -4.091 & 0.008 & -5.147 & 0.000 \\
\hline & & PP & -11.776 & 0.000 & -7.211 & 0.000 \\
\hline \multirow[t]{4}{*}{ Norway } & Level & ADF & -1.522 & 0.518 & -0.451 & 0.985 \\
\hline & & $\mathrm{PP}$ & -1.817 & 0.370 & -0.593 & 0.978 \\
\hline & F. D. $(\Delta)$ & ADF & -8.831 & 0.000 & -15.829 & 0.000 \\
\hline & & $\mathrm{PP}$ & -12.871 & 0.000 & -15.644 & 0.000 \\
\hline \multirow[t]{4}{*}{ Poland } & Level & ADF & -2.698 & 0.244 & -1.648 & 0.765 \\
\hline & & PP & -2.378 & 0.384 & -1.494 & 0.824 \\
\hline & F. D. $(\Delta)$ & ADF & -3.824 & 0.029 & -10.109 & 0.000 \\
\hline & & PP & -8.156 & 0.000 & -10.507 & 0.000 \\
\hline \multirow[t]{4}{*}{ Portugal } & Level & ADF & -2.414 & 0.370 & -2.271 & 0.444 \\
\hline & & PP & -2.923 & 0.161 & -1.923 & 0.633 \\
\hline & F. D. $(\Delta)$ & ADF & -7.311 & 0.000 & -4.397 & 0.004 \\
\hline & & $\mathrm{PP}$ & -7.185 & 0.000 & -7.221 & 0.000 \\
\hline \multirow[t]{4}{*}{ Russian Federation } & Level & $A D F$ & -1.693 & 0.749 & -2.659 & 0.256 \\
\hline & & $\mathrm{PP}$ & -1.555 & 0.806 & -1.592 & 0.791 \\
\hline & F. D. $(\Delta)$ & $A D F$ & -4.091 & 0.008 & -5.147 & 0.000 \\
\hline & & PP & -11.776 & 0.000 & -7.211 & 0.000 \\
\hline \multirow[t]{4}{*}{ Singapore } & Level & ADF & -1.998 & 0.287 & -1.607 & 0.476 \\
\hline & & $\mathrm{PP}$ & -1.751 & 0.401 & -1.485 & 0.538 \\
\hline & F. D. $(\Delta)$ & $A D F$ & -4.411 & 0.001 & -3.681 & 0.005 \\
\hline & & $\mathrm{PP}$ & -8.936 & 0.000 & -9.088 & 0.000 \\
\hline South Africa & Level & $A D F$ & -2.895 & 0.169 & -2.316 & 0.422 \\
\hline
\end{tabular}


Table 3. Unit root tests. (Continued)

\begin{tabular}{|c|c|c|c|c|c|c|}
\hline \multirow[b]{2}{*}{ Country } & & \multirow[b]{2}{*}{ Test } & \multirow{2}{*}{$\frac{\text { FUTURES }}{\text { t-stat. }}$} & \multirow[b]{2}{*}{$p$-value } & \multirow{2}{*}{$\frac{\text { RGDPC }}{\text { t-stat. }}$} & \multirow[b]{2}{*}{$p$-value } \\
\hline & & & & & & \\
\hline & & PP & -3.107 & 0.110 & -2.219 & 0.475 \\
\hline & F. D. $(\triangle)$ & ADF & -10.938 & 0.000 & -4.308 & 0.004 \\
\hline & & PP & -10.933 & 0.000 & -6.857 & 0.000 \\
\hline \multirow[t]{4}{*}{ Spain } & Level & ADF & -3.147 & 0.103 & -2.086 & 0.545 \\
\hline & & PP & -2.988 & 0.142 & -1.014 & 0.936 \\
\hline & F. D. $(\triangle)$ & ADF & -5.743 & 0.000 & -4.219 & 0.007 \\
\hline & & PP & -11.766 & 0.000 & -2.517 & 0.319 \\
\hline \multirow[t]{4}{*}{ Sweden } & Level & ADF & -2.868 & 0.185 & -0.983 & 0.940 \\
\hline & & PP & -3.472 & 0.056 & -1.198 & 0.904 \\
\hline & F. D. $(\triangle)$ & ADF & -7.455 & 0.000 & -4.953 & 0.001 \\
\hline & & PP & -7.547 & 0.000 & -6.979 & 0.000 \\
\hline \multirow[t]{4}{*}{ Switzerland } & Level & ADF & -2.646 & 0.262 & -2.923 & 0.159 \\
\hline & & PP & -2.475 & 0.340 & -2.331 & 0.414 \\
\hline & F. D. $(\Delta)$ & ADF & -13.864 & 0.000 & -6.580 & 0.000 \\
\hline & & PP & -13.781 & 0.000 & -6.542 & 0.000 \\
\hline \multirow[t]{4}{*}{ Thailand } & Level & ADF & 2.109 & 1.000 & -0.598 & 0.865 \\
\hline & & $\mathrm{PP}$ & 1.371 & 0.999 & -0.598 & 0.865 \\
\hline & F. D. $(\triangle)$ & ADF & -3.847 & 0.006 & -9.156 & 0.000 \\
\hline & & PP & -3.674 & 0.009 & -9.156 & 0.000 \\
\hline \multirow[t]{4}{*}{ Turkey } & Level & ADF & -1.360 & 0.858 & -2.849 & 0.186 \\
\hline & & PP & -1.254 & 0.885 & -2.509 & 0.323 \\
\hline & F. D. $(\triangle)$ & ADF & -7.167 & 0.000 & -6.002 & 0.000 \\
\hline & & PP & -7.167 & 0.000 & -6.011 & 0.000 \\
\hline \multirow[t]{4}{*}{ United Kingdom } & Level & ADF & -0.987 & 0.757 & -2.054 & 0.264 \\
\hline & & PP & -1.199 & 0.674 & -2.407 & 0.142 \\
\hline & F. D. $(\Delta)$ & ADF & -10.579 & 0.000 & -4.309 & 0.001 \\
\hline & & $\mathrm{PP}$ & -17.959 & 0.000 & -5.977 & 0.000 \\
\hline \multirow[t]{4}{*}{ United States } & Level & ADF & -1.693 & 0.749 & -2.659 & 0.256 \\
\hline & & $\mathrm{PP}$ & -1.555 & 0.806 & -1.592 & 0.791 \\
\hline & F. D. $(\triangle)$ & ADF & -4.091 & 0.008 & -5.147 & 0.000 \\
\hline & & $\mathrm{PP}$ & -11.776 & 0.000 & -7.211 & 0.000 \\
\hline
\end{tabular}

Notes: ADF: Augmented Dickey-Fuller Test and PP: Phillips-Perron Test. Both tests have the Ho: There is unit root. Constant and trend are included in the ADF and PP test equations. F. D. ( $\Delta$ ):First difference operator, the change in the variable. We perform Kwiatkowski-Phillips-Schmidt-Shin (KPSS) test for the series that showed inconsistency between the ADF and PP tests for Spain and Sweden. KPSS test results confirmed the existence of unit root of the level series and stationarity of the first differenced series. Results of KPSS tests are available upon request.

Our results are in line with the existing literature. Rioja and Valev (2004) propose that financial development and economic growth relationship may vary according to the level of financial development, and the authors add that: in the countries with very low levels of financial development, in the low region, additional improvements in financial markets have an uncertain effect on growth, whereas in the intermediate region, financial development has a large, positive effect on growth. Our findings are also consistent with Calderon and Liu (2003), who find that financial deepening contributes more to the causal relationship in developing countries than in industrialized ones ${ }^{10}$ Similarly, Shen and Lee (2006) state that the relationship between financial development and economic growth may not be linear, but rather be dependent on the economic and financial conditions. 
Table 4. Johansen cointegration tests (trace test).

\begin{tabular}{|c|c|c|c|c|c|}
\hline \multirow{2}{*}{$\begin{array}{l}\text { Series } \\
\text { Country }\end{array}$} & \multicolumn{5}{|l|}{ FUTURES and RGDPC } \\
\hline & $\begin{array}{l}\text { Hypothesized number } \\
\text { of } C E(s)\end{array}$ & Eigenvalue & Trace statistics & $\begin{array}{l}0.05 \\
\text { Critical value }\end{array}$ & $p$-Value \\
\hline \multirow[t]{2}{*}{ Australia } & None & 0.412 & 24.699 & 15.495 & 0.002 \\
\hline & At most 1 & 0.018 & 0.830 & 3.841 & 0.362 \\
\hline \multirow[t]{2}{*}{ Austria } & None & 0.431 & 41.506 & 15.495 & 0.000 \\
\hline & At most 1 & 0.100 & 6.532 & 3.841 & 0.011 \\
\hline \multirow[t]{2}{*}{ Belgium } & None & 0.146 & 17.595 & 15.495 & 0.024 \\
\hline & At most 1 & 0.076 & 5.881 & 3.841 & 0.015 \\
\hline \multirow[t]{2}{*}{ Brazil } & None & 0.172 & 14.199 & 15.495 & 0.078 \\
\hline & At most 1 & 0.036 & 2.318 & 3.841 & 0.128 \\
\hline \multirow[t]{2}{*}{ Canada } & None & 0.239 & 15.282 & 15.495 & 0.054 \\
\hline & At most 1 & 0.038 & 1.882 & 3.841 & 0.170 \\
\hline \multirow[t]{2}{*}{ China } & None & 0.815 & 25.784 & 15.495 & 0.001 \\
\hline & At most 1 & 0.369 & 5.533 & 3.841 & 0.019 \\
\hline \multirow[t]{2}{*}{ Denmark } & None & 0.861 & 20.124 & 15.495 & 0.009 \\
\hline & At most 1 & 0.233 & 2.392 & 3.841 & 0.122 \\
\hline \multirow[t]{2}{*}{ France } & None & 0.151 & 14.542 & 15.495 & 0.069 \\
\hline & At most 1 & 0.075 & 4.696 & 3.841 & 0.030 \\
\hline \multirow[t]{2}{*}{ Germany } & None & 0.065 & 6.244 & 15.495 & 0.667 \\
\hline & At most 1 & 0.005 & 0.432 & 3.841 & 0.511 \\
\hline \multirow[t]{2}{*}{ Greece } & None & 0.235 & 20.471 & 15.495 & 0.008 \\
\hline & At most 1 & 0.093 & 5.475 & 3.841 & 0.019 \\
\hline \multirow[t]{2}{*}{ Hong Kong, China } & None & 0.125 & 15.923 & 15.495 & 0.043 \\
\hline & At most 1 & 0.008 & 0.933 & 3.841 & 0.334 \\
\hline \multirow[t]{2}{*}{ Hungary } & None & 0.258 & 22.551 & 15.495 & 0.004 \\
\hline & At most 1 & 0.019 & 1.392 & 3.841 & 0.238 \\
\hline \multirow[t]{2}{*}{ India } & None & 0.279 & 15.231 & 15.495 & 0.055 \\
\hline & At most 1 & 0.003 & 0.156 & 3.841 & 0.693 \\
\hline \multirow[t]{2}{*}{ Italy } & None & 0.870 & 61.548 & 15.495 & 0.000 \\
\hline & At most 1 & 0.012 & 0.366 & 3.841 & 0.545 \\
\hline \multirow[t]{2}{*}{ Japan } & None & 0.190 & 16.010 & 15.495 & 0.042 \\
\hline & At most 1 & 0.008 & 0.611 & 3.841 & 0.435 \\
\hline \multirow[t]{2}{*}{ Korea, Rep. } & None & 0.223 & 24.087 & 15.495 & 0.002 \\
\hline & At most 1 & 0.106 & 7.401 & 3.841 & 0.007 \\
\hline \multirow[t]{2}{*}{ Malaysia } & None & 0.998 & 106.639 & 15.495 & 0.000 \\
\hline & At most 1 & 0.889 & 28.587 & 3.841 & 0.000 \\
\hline \multirow[t]{2}{*}{ Mexico } & None & 0.263 & 18.353 & 15.495 & 0.018 \\
\hline & At most 1 & 0.054 & 2.819 & 3.841 & 0.093 \\
\hline \multirow[t]{2}{*}{ The Netherlands } & None & 0.146 & 19.328 & 15.495 & 0.013 \\
\hline & At most 1 & 0.105 & 7.951 & 3.841 & 0.005 \\
\hline Norway & None & 0.239 & 29.672 & 15.495 & 0.000 \\
\hline & At most 1 & 0.070 & 6.226 & 3.841 & 0.013 \\
\hline Poland & None & 0.641 & 37.906 & 15.495 & 0.000 \\
\hline & At most 1 & 0.503 & 15.365 & 3.841 & 0.000 \\
\hline Portugal & None & 0.269 & 24.315 & 15.495 & 0.002 \\
\hline & At most 1 & 0.082 & 5.219 & 3.841 & 0.022 \\
\hline Russian Federation & None & 0.897 & 84.921 & 15.495 & 0.000 \\
\hline & At most 1 & 0.631 & 25.902 & 3.841 & 0.000 \\
\hline Singapore & None & 0.345 & 21.972 & 15.495 & 0.005 \\
\hline & At most 1 & 0.000 & 0.008 & 3.841 & 0.928 \\
\hline
\end{tabular}


Table 4. Johansen cointegration tests (trace test). (Continued)

\begin{tabular}{|c|c|c|c|c|c|}
\hline \multirow{2}{*}{$\begin{array}{l}\text { Series } \\
\text { Country }\end{array}$} & \multicolumn{5}{|l|}{ FUTURES and RGDPC } \\
\hline & $\begin{array}{l}\text { Hypothesized number } \\
\text { of CE(s) }\end{array}$ & Eigenvalue & Trace statistics & $\begin{array}{l}0.05 \\
\text { Critical value }\end{array}$ & $p$-Value \\
\hline \multirow[t]{2}{*}{ South Africa } & None & 0.134 & 13.606 & 15.495 & 0.094 \\
\hline & At most 1 & 0.000 & 0.034 & 3.841 & 0.853 \\
\hline \multirow[t]{2}{*}{ Spain } & None & 0.162 & 16.379 & 15.495 & 0.037 \\
\hline & At most 1 & 0.059 & 4.185 & 3.841 & 0.041 \\
\hline \multirow[t]{2}{*}{ Sweden } & None & 0.724 & 35.221 & 15.495 & 0.000 \\
\hline & At most 1 & 0.017 & 0.459 & 3.841 & 0.498 \\
\hline \multirow[t]{2}{*}{ Switzerland } & None & 0.081 & 8.325 & 15.495 & 0.431 \\
\hline & At most 1 & 0.006 & 0.519 & 3.841 & 0.471 \\
\hline \multirow[t]{2}{*}{ Thailand } & None & 0.942 & 69.034 & 15.495 & 0.000 \\
\hline & At most 1 & 0.026 & 0.635 & 3.841 & 0.426 \\
\hline \multirow[t]{2}{*}{ Turkey } & None & 0.958 & 116.142 & 15.495 & 0.000 \\
\hline & At most 1 & 0.678 & 30.623 & 3.841 & 0.000 \\
\hline \multirow[t]{2}{*}{ United Kingdom } & None & 0.162 & 20.852 & 15.495 & 0.007 \\
\hline & At most 1 & 0.015 & 1.627 & 3.841 & 0.202 \\
\hline \multirow[t]{2}{*}{ United States } & None & 0.032 & 6.412 & 15.495 & 0.647 \\
\hline & At most 1 & 0.018 & 2.285 & 3.841 & 0.131 \\
\hline
\end{tabular}

Notes: CE is the abbreviation for cointegrating equation.

\section{Vector Error Correction Models, Variance Decomposition, and IRF Analyses}

A cointegration in stock index futures and the real economy indicates long-run stationarity, but provides no information about the speed of adjustments of the variables to deviations from their common stochastic trend. Existence of cointegration between FUTURES and RGDPC series in 29 countries leads us to use the VECM in those countries to correct the deviation from the long-run equilibrium, as Engle and Granger (1987) suggest. We construct the following VECM. The fourth component of each equation is the error correction term (ECT) that is formed with the cointegrating vector. Sign and size of the coefficient of the ECT in each equation reflect the direction and speed of adjustments in the dependent variable to deviations from the linear long-run relationship.

$$
\begin{aligned}
& \triangle F U T U R E S_{t}=d_{1}+a_{11}(L) \Delta F U T U R E S_{t-1}+a_{12}(L) \Delta R G D P C_{t-1}+ \\
& g_{1}\left(\text { FUTURES }_{t-1}+b_{12} \text { RGDPC }_{t-1}+c_{0}\right)+\varepsilon_{1 t} \\
& \triangle R G D P C_{t}=d_{2}+a_{21}(L) \Delta F U T U R E S_{t-1}+a_{22}(L) \Delta R G D P C_{t-1}+ \\
& g_{2}\left(\text { FUTURES }_{t-1}+b_{12} \text { RGDPC }_{t-1}+c_{0}\right)+\varepsilon_{2 t}
\end{aligned}
$$

where $\Delta$ is the change operator; $d_{1}, d_{2}$, and $c_{0}$ are constants; $L$ is the lag operator $\left[a_{11}(L): a_{11.0} L^{\circ}+a_{11.1}\right.$ $L^{1}+\ldots$ (a polynomial in L)]; $g_{1}$ and $g_{2}$ are the adjustment parameters; and $b_{12}$ is the cointegration coefficient. For the other three countries, namely Germany, Switzerland, and the United States, where we could not observe cointegration between FUTURES and RGDPC, we simply used the Vector Autoregression Model (VAR). VECMs and VARs are used in the calculations of variance decomposition and IRF among stock index futures market and real economy.

In 22 countries, namely in Australia, Austria, Brazil, China, France, Greece, Hungary, India, Italy, Malaysia, Mexico, the Netherlands, Norway, Poland, Russian Fed., Singapore, South Africa, Spain, Sweden, Thailand, Turkey, and the United Kingdom, variance decomposition results suggest innovations in FUTURES explain substantial amounts of the variation in RGDPC as the number of periods 
Table 5. Granger-causality/block exogeneity Wald tests.

\begin{tabular}{|c|c|c|c|c|c|c|}
\hline & $\begin{array}{c}\text { Dep.Var.: } \Delta \text { RGDPC } \\
\text { Excluded: } \Delta \text { FUTURES } \\
\Delta \text { FUTURES } \Rightarrow \Delta \text { RGDPC }\end{array}$ & & & $\begin{array}{l}\text { Dep.Var.: } \Delta \text { FUTURES } \\
\text { Excluded: } \Delta \text { RGDPC } \\
\Delta \text { RGDPC } \Rightarrow \Delta \text { FUTURES }\end{array}$ & & \\
\hline Country & Chi-square statistics & df & $p$-Value & Chi-square statistics & Df & $p$-Value \\
\hline Australia & 12.733 & 1 & 0.001 & 0.620 & 1 & 0.434 \\
\hline Austria & 0.526 & 9 & 0.848 & 3.547 & 9 & 0.002 \\
\hline Belgium & 2.658 & 3 & 0.055 & 2.264 & 3 & 0.089 \\
\hline Brazil & 2.684 & 4 & 0.040 & 1.609 & 4 & 0.183 \\
\hline Canada & 1.822 & 11 & 0.102 & 1.332 & 11 & 0.263 \\
\hline China & 9.592 & 4 & 0.097 & 1.185 & 4 & 0.505 \\
\hline Denmark & 0.676 & 3 & 0.689 & 4.852 & 3 & 0.319 \\
\hline France & 2.231 & 2 & 0.117 & 3.836 & 2 & 0.028 \\
\hline Germany & 0.620 & 1 & 0.433 & 11.525 & 1 & 0.001 \\
\hline Greece & 1.747 & 10 & 0.117 & 2.309 & 10 & 0.039 \\
\hline Hong Kong, China & 1.735 & 2 & 0.181 & 3.926 & 2 & 0.023 \\
\hline Hungary & 4.313 & 8 & 0.001 & 0.753 & 8 & 0.645 \\
\hline India & 4.771 & 2 & 0.013 & 1.866 & 2 & 0.165 \\
\hline Italy & 1.547 & 5 & 0.210 & 2.376 & 5 & 0.067 \\
\hline Japan & 0.122 & 1 & 0.727 & 4.731 & 1 & 0.033 \\
\hline Korea, Rep. & 1.149 & 2 & 0.323 & 0.156 & 2 & 0.856 \\
\hline Malaysia & 0.361 & 5 & 0.849 & 2.510 & 5 & 0.240 \\
\hline Mexico & 2.117 & 12 & 0.057 & 0.755 & 12 & 0.687 \\
\hline The Netherlands & 0.297 & 1 & 0.588 & 3.378 & 1 & 0.070 \\
\hline Norway & 1.994 & 12 & 0.044 & 1.783 & 12 & 0.077 \\
\hline Poland & 0.481 & 6 & 0.810 & 2.549 & 6 & 0.085 \\
\hline Portugal & 1.244 & 8 & 0.293 & 1.782 & 8 & 0.090 \\
\hline Russian Federation & 0.511 & 11 & 0.813 & 0.677 & 11 & 0.730 \\
\hline Singapore & 0.487 & 3 & 0.693 & 4.867 & 3 & 0.004 \\
\hline South Africa & 2.598 & 2 & 0.080 & 0.954 & 2 & 0.389 \\
\hline Spain & 0.328 & 5 & 0.894 & 2.022 & 5 & 0.088 \\
\hline Sweden & 2.023 & 9 & 0.144 & 3.614 & 9 & 0.029 \\
\hline Switzerland & 0.926 & 2 & 0.400 & 2.409 & 2 & 0.096 \\
\hline Thailand & 0.090 & 10 & 0.997 & 1.021 & 10 & 0.591 \\
\hline Turkey & 0.141 & 12 & 0.979 & 12.139 & 12 & 0.221 \\
\hline United Kingdom & 0.453 & 3 & 0.716 & 2.570 & 3 & 0.058 \\
\hline United States & 1.756 & 2 & 0.177 & 1.797 & 2 & 0.170 \\
\hline
\end{tabular}

Notes: Ho: (i) change in FUTURES does not Granger-cause change in RGDPC, (ii) change in RGDPC does not Grangercause change in FUTURES, respectively. 1-12 lags are tried, the lag minimizing the Akaike Information Criterion (AIC) is chosen. F. D. $(\Delta)$ : First difference operator, the change in the variable.

increase. In 21 countries, namely in Austria, Canada, China, France, Germany, Greece, Hong Kong Ch., India, Italy, Japan, Poland, Portugal, Russian Fed., Singapore, South Africa, Spain, Sweden, Switzerland, Thailand, Turkey, and the United Kingdom, variance decomposition results suggest innovations in RGDPC explain substantial amounts of the variation in FUTURES as the number of periods increases. These findings imply interdependence of the stock index futures and the real economy. Variance decompositions analyses results are presented in Table A1. To reinforce our results, we perform the Residual Serial Correlation LM Test, which has a null hypothesis of no serial correlation. Test results show that we observe no serial correlation in all countries in almost all lags. Residual Serial Correlation LM Test results are presented in Table A2. 
For a robustness check we perform IRF analyses. Our results indicate that stock index futures markets development and economic growth affect each other. We observe that one standard deviation FUTURES innovation affects RGDPC, and one standard deviation RGDPC innovation affects FUTURES for the analysis period of 12 quarters for the countries in our data set. Exceptionally for Denmark, the effect of one standard deviation RGDPC innovation to FUTURES is almost zero. ${ }^{11}$

\section{Conclusion}

In this article, we investigate the relationship between stock index futures markets development and economic growth using time-series methods for 32 developed and developing countries. Evidence of cointegration between stock index futures markets and real per capita GDP in the countries in our sample suggests the presence of co-movements among the variables, indicating long-run stationarity. Our results show unidirectional Granger-causality between stock index futures markets development and economic growth in 22 countries. We observe significant causality from futures markets development to economic growth in Australia, Brazil, China, Hungary, India, Mexico, and South Africa, most of which are middle-income countries and have relatively low real per capita GDP levels among the countries in our sample. We observe unidirectional Granger-causality in the reverse direction, i.e. from economic growth to futures markets development, in Austria, France, Germany, Greece, Hong Kong-China, Italy, Japan, the Netherlands, Poland, Portugal, Singapore, Spain, Sweden, Switzerland, and the United Kingdom, which have high real per capita GDP levels. Variance decomposition and IRF analyses results also support the existence of a relationship between stock index futures markets and real per capita GDP.

Our results are intuitive. On the one hand, well-functioning futures markets allow for greater and more efficient risk sharing, thereby making it possible for firms to undertake relatively riskier projects and, hence, promote growth. On the other hand, futures markets widely distribute equilibrium prices that reflect demand and supply conditions, and knowledge of those prices allows investors, consumers, and producers to make informed decisions. Consequently, the amelioration of information and transaction costs fosters efficient resource allocation, thus leading to economic growth. Middle-income economies benefit more from the increase in the efficiency of resource allocation. Our findings have important policy implications. Government policies to promote derivative markets may help lead to a higher economic growth, especially for middle-income countries.

\section{Notes}

1. See Levine (2005) for a survey. See Wachtel (2001) for a summary of consensus and discussion of the techniques that have been used in the related literature.

2. See also Cyree, Huang, and Lindley (2011) for a discussion of function of banks' derivatives use.

3. See Jeong, Kymn, and Kymn (2003), Berger, Hasan, and Klapper (2004), Şendeniz-Yüncü, Akdeniz, and Aydoğan (2008), and Cheng and Degryse (2010) for further analysis of the impact of banking sector on economic growth.

4. See also Saci, Giorgioni, and Holden (2009) for a discussion of the impact of both stock market and banking sector developments on growth using GMM panel techniques.

5. See also Baluch and Ariff (2007) and Bekale, Botha, and Vermeulen (2015) for discussions of derivative markets and economic growth relationships.

6. Smith and Stulz (1985) argue that by reducing the variability of the future value of the firm, hedging lowers the probability of incurring bankruptcy costs, and benefits shareholder.

7. EViews 7 is used for all the analyses.

8. KPSS test results are available upon request.

9. Source for GDP growth (annual \%) and gross fixed capital formation (annual \% growth) data for Hungary is the World Bank.

10. See also Wachtel (2003) for the discussions of different levels of effects of finance on economic growth in countries with different income levels.

11. IRF analyses results are available upon request. 


\section{References}

Acemoglu, D., and F. Zilibotti. 1997. Was Prometheus unbound by chance? Risk, diversification, and growth. Journal of Political Economy 105:709-51. doi:10.1086/262091.

Angeletos, G. M., and L. E. Calvet. 2006. Idiosyncratic production risk, growth and the business cycle. Journal of Monetary Economics 53:1095-115.

Arestis, P., P. O. Demetriades, and K. B. Luintel. 2001. Financial development and economic growth: The role of stock markets. Journal of Money, Credit and Banking 33 (1):16-41. doi:10.2307/2673870.

Atje, R., and B. Jovanovic. 1993. Stock markets and development. European Economic Review 37:632-40. doi:10.1016/00142921(93)90053-D.

Baier, S. L., G. P. Dwyer Jr., and R. Tamura. 2004. Does opening a stock exchange increase economic growth? Journal of International Money and Finance 23:311-31. doi:10.1016/j.jimonfin.2004.01.001.

Baluch, A., and M. Ariff. 2007. Derivative markets and economic growth: Is there a relationship? Bond University Globalisation \& Development Centre Working Paper Series No. 13. Bond University.

Beck, T., and R. Levine. 2004. Stock markets, banks, and growth: Panel evidence. Journal of Banking \& Finance 28:423-42.

Beck, T., R. Levine, and N. Loayza. 2000. Finance and the sources of growth. Journal of Financial Economics 58 (1-2):261300. doi:10.1016/S0304-405X(00)00072-6.

Bekale, A. N., E. Botha, and J. Vermeulen. 2015. Institutionalisation of derivatives trading and economic growth: Evidence from South Africa. Economic Research South Africa working paper 505. ERSA.

Berger, A. N., I. Hasan, and L. F. Klapper. 2004. Further evidence on the link between finance and growth: An international analysis of community banking and economic performance. Journal of Financial Services Research 25:169-202. doi:10.1023/B:FINA.0000020659.33510.b7.

Calderon, C., and L. Liu. 2003. The Direction of causality between financial development and economic growth. Journal of Development Economics 72:321-34. doi:10.1016/S0304-3878(03)00079-8.

Cheng, X., and H. Degryse. 2010. The impact of bank and non-bank financial institutions on local economic growth in China. Journal of Financial Services Research 37:179-99. doi:10.1007/s10693-009-0077-4.

Cyree, K. B., P. Huang, and J. T. Lindley. 2011. The economic consequences of banks' derivatives use in good times and bad times. Journal of Financial Services Research 41:121-44. doi:10.1007/s10693-011-0106-y.

Demirgüç-Kunt, A., and R. Levine. 1996a. Stock markets corporate finance and economic growth. World Bank Economic Review 10 (2):223-40. doi:10.1093/wber/10.2.223.

Demirgüç-Kunt, A., and R. Levine. 1996b. Stock market development and financial intermediaries: Stylized facts. World Bank Economic Review 10 (2):291-322. doi:10.1093/wber/10.2.291.

Engle, R. F., and C. W. J. Granger. 1987. Co-integration and error correction: Representation, estimation and testing. Econometrica 55:251-76. doi:10.2307/1913236.

Goldsmith, R. W. 1969. Financial structure and development. New Haven, CT: Yale University Press.

Haiss, P., and B. Sammer. 2010. The impact of derivatives markets on financial integration, risk, and economic growth. SSRN Electronic Journal. doi:10.2139/ssrn.1720586.

Harris, R. D. F. 1997. Stock markets and development: A re-assessment. European Economic Review 41:139-46. doi:10.1016/ S0014-2921(96)00021-9.

Jeong, W., K. O. Kymn, and C. J. Kymn. 2003. The long-run interdependence of bank-health, investment-oriented bank loans, and economic performance: A time-series analysis. The Quarterly Review of Economics and Finance 43:11-30. doi:10.1016/ S1062-9769(01)00090-4.

Kenourgios, D., A. Samitas, and P. Drosos. 2008. Hedge ratio estimation and hedging effectiveness: The case of the S\&P 500 stock index futures contract. International Journal of Risk Assessment and Management 9:121-34. doi:10.1504/ IJRAM.2008.019316.

King, R. G., and R. Levine. 1993. Finance and growth: Schumpeter might be right. The Quarterly Journal of Economics 108:717-37. doi:10.2307/2118406.

Krebs, T. 2002. Growth and welfare effects of business cycles in economies with idiosyncratic human capital risk. Review of Economic Dynamics 6:846-68. doi:10.1016/S1094-2025(03)00030-9.

Levine, R. 2005. Finance and growth: Theory and evidence. In Handbook of economic growth, eds. P. Aghion, and S. Durlauf, vol. 1, 865-934. Part 1. Amsterdam: North-Holland Elsevier.

Levine, R., N. Loayza, and T. Beck. 2000. Financial intermediation and growth: Causality and causes. Journal of Monetary Economics 46:31-77. doi:10.1016/S0304-3932(00)00017-9.

Levine, R., and S. Zervos. 1998. Stock markets, banks, and economic growth. The American Economic Review 88 (3):537-58.

Lin, J. Y., X. Sun, and Y. Jiang 2009. Toward a theory of optimal financial structure. World Bank Policy Research Working Paper. The World Bank.

Merton, R. C., and Z. Bodie. 1995. A conceptual framework for analyzing the financial environment. In The global financial system, eds. D. B. Crane, K. A. Froot, S. P. Mason, A. F. Perold, R. C. Merton, Z. Bodie, E. R. Sirri, and P. Tufano, 1-31. Boston: Harvard Business School Press.

Rioja, F., and N. Valev. 2004. Does one size fit all? A reexamination of the finance and growth relationship. Journal of Development Economics 74:429-47. doi:10.1016/j.jdeveco.2003.06.006.

Rousseau, P. L., and P. Wachtel. 1998. Financial intermediation and economic performance: Historical evidence from five industrial countries. Journal of Money, Credit and Banking 30:657-78. doi:10.2307/2601123.

Saci, K., G. Giorgioni, and K. Holden. 2009. Does financial development affect growth? Applied Economics 41:1701-07. doi:10.1080/00036840701335538.

Şendeniz-Yüncü, İ., L. Akdeniz, and K. Aydoğan. 2008. Interdependence of the banking sector and the real sector: Evidence from OECD countries. Applied Economics 40:749-64. doi:10.1080/00036840600735424. 
Shen, C., and C. Lee. 2006. Same financial development yet different economic growth-Why? Journal of Money, Credit and Banking 38:1907-44. doi:10.1353/mcb.2006.0095.

Smith, C. W., and R. M. Stulz. 1985. The determinants of firms' hedging policies. The Journal of Financial and Quantitative Analysis 20:391-405. doi:10.2307/2330757.

Storesletten, K., C. I. Telmer, and A. Yaron. 2004. Cyclical dynamics in idiosyncratic labor-market risk. Journal of Political Economy 112:695-717. doi:10.1086/383105.

Turnovsky, S. J., and M. Bianconi. 2005. The welfare gains from stabilization in a stochastically growing economy with idiosyncratic shocks and flexible labor supply. Macroeconomic Dynamics 9:321-57. doi:10.1017/S1365100505040228.

Wachtel, P. 2001. Growth and finance: What do we know and how do we know it? International Finance 4:335-62. doi:10.1111/ infi.2001.4.issue-3.

Wachtel, P. 2003. How much do we really know about growth and finance? Fed Reserve Bank Atlanta, Economic Review $33-47$. 


\section{APPENDIX}

Table A1. Variance decompositions.

\begin{tabular}{|c|c|c|c|c|c|c|c|}
\hline \multirow[b]{2}{*}{ Country } & \multirow[b]{2}{*}{ Period } & \multicolumn{3}{|c|}{ FUTURES } & \multicolumn{3}{|c|}{ RGDPC } \\
\hline & & S.E. & $\begin{array}{c}\varepsilon_{1 \mathrm{t}} \\
\text { (FUTURES) }\end{array}$ & $\begin{array}{c}\varepsilon_{2 t} \\
(R G D P C)\end{array}$ & S.E. & $\begin{array}{c}\varepsilon_{1 \mathrm{t}} \\
\text { (FUTURES) }\end{array}$ & $\begin{array}{c}\varepsilon_{2 t} \\
(R G D P C)\end{array}$ \\
\hline \multirow[t]{4}{*}{ Australia } & 1 & 0.095 & 100.000 & 0.000 & 0.003 & 5.962 & 94.038 \\
\hline & 2 & 0.134 & 98.123 & 1.877 & 0.005 & 13.044 & 86.956 \\
\hline & 11 & 0.233 & 94.820 & 5.180 & 0.007 & 26.959 & 73.041 \\
\hline & 12 & 0.234 & 94.863 & 5.137 & 0.007 & 29.314 & 70.686 \\
\hline \multirow[t]{4}{*}{ Austria } & 1 & 0.004 & 100.000 & 0.000 & 0.008 & 6.227 & 93.773 \\
\hline & 2 & 0.004 & 98.420 & 1.580 & 0.013 & 20.813 & 79.187 \\
\hline & 11 & 0.006 & 81.447 & 18.553 & 0.032 & 35.104 & 64.896 \\
\hline & 12 & 0.007 & 82.435 & 17.565 & 0.032 & 35.358 & 64.642 \\
\hline \multirow[t]{4}{*}{ Belgium } & 1 & 0.008 & 100.000 & 0.000 & 0.004 & 0.013 & 99.987 \\
\hline & 2 & 0.010 & 99.282 & 0.718 & 0.009 & 0.082 & 99.918 \\
\hline & 11 & 0.024 & 96.791 & 3.209 & 0.023 & 2.376 & 97.624 \\
\hline & 12 & 0.024 & 96.047 & 3.953 & 0.024 & 2.296 & 97.704 \\
\hline \multirow[t]{4}{*}{ Brazil } & 1 & 0.038 & 100.000 & 0.000 & 0.011 & 8.193 & 91.807 \\
\hline & 2 & 0.066 & 98.183 & 1.817 & 0.017 & 10.778 & 89.222 \\
\hline & 11 & 0.121 & 96.342 & 3.658 & 0.041 & 26.411 & 73.589 \\
\hline & 12 & 0.121 & 96.120 & 3.880 & 0.043 & 25.714 & 74.286 \\
\hline \multirow[t]{4}{*}{ Canada } & 1 & 0.026 & 100.000 & 0.000 & 0.005 & 9.560 & 90.440 \\
\hline & 2 & 0.031 & 96.529 & 3.471 & 0.010 & 20.562 & 79.438 \\
\hline & 11 & 0.055 & 84.632 & 15.368 & 0.026 & 9.538 & 90.462 \\
\hline & 12 & 0.057 & 79.461 & 20.539 & 0.027 & 8.498 & 91.502 \\
\hline \multirow[t]{4}{*}{ China } & 1 & 0.032 & 100.000 & 0.000 & 0.103 & 6.856 & 93.144 \\
\hline & 2 & 0.047 & 83.992 & 16.008 & 0.106 & 11.408 & 88.592 \\
\hline & 11 & 0.088 & 57.228 & 42.772 & 0.152 & 35.838 & 64.162 \\
\hline & 12 & 0.092 & 56.699 & 43.301 & 0.155 & 36.692 & 63.308 \\
\hline \multirow{4}{*}{ Denmark } & 1 & 0.003 & 100.000 & 0.000 & 0.004 & 65.503 & 34.497 \\
\hline & 2 & 0.003 & 99.336 & 0.664 & 0.005 & 51.932 & 48.068 \\
\hline & 11 & 0.003 & 99.267 & 0.733 & 0.011 & 17.827 & 82.173 \\
\hline & 12 & 0.003 & 99.267 & 0.733 & 0.011 & 17.189 & 82.811 \\
\hline \multirow[t]{4}{*}{ France } & 1 & 0.115 & 100.000 & 0.000 & 0.004 & 0.377 & 99.623 \\
\hline & 2 & 0.152 & 95.190 & 4.810 & 0.008 & 4.630 & 95.370 \\
\hline & 11 & 0.381 & 88.611 & 11.389 & 0.018 & 13.272 & 86.728 \\
\hline & 12 & 0.398 & 88.854 & 11.146 & 0.018 & 13.944 & 86.056 \\
\hline \multirow[t]{4}{*}{ Germany } & 1 & 0.273 & 100.000 & 0.000 & 0.008 & 0.836 & 99.164 \\
\hline & 2 & 0.366 & 92.391 & 7.609 & 0.014 & 1.871 & 98.129 \\
\hline & 11 & 0.700 & 72.965 & 27.035 & 0.038 & 4.544 & 95.456 \\
\hline & 12 & 0.716 & 71.854 & 28.146 & 0.040 & 4.743 & 95.257 \\
\hline \multirow[t]{4}{*}{ Greece } & 1 & 0.016 & 100.000 & 0.000 & 0.013 & 29.111 & 70.889 \\
\hline & 2 & 0.023 & 79.133 & 20.867 & 0.018 & 28.632 & 71.368 \\
\hline & 11 & 0.064 & 49.984 & 50.016 & 0.102 & 50.824 & 49.176 \\
\hline & 12 & 0.067 & 50.555 & 49.445 & 0.115 & 50.035 & 49.965 \\
\hline \multirow[t]{4}{*}{ Hong Kong, China } & 1 & 0.001 & 100.000 & 0.000 & 0.017 & 0.865 & 99.135 \\
\hline & 2 & 0.001 & 91.708 & 8.292 & 0.026 & 0.480 & 99.520 \\
\hline & 11 & 0.002 & 71.494 & 28.506 & 0.069 & 1.681 & 98.319 \\
\hline & 12 & 0.002 & 69.813 & 30.187 & 0.070 & 1.641 & 98.359 \\
\hline Hungary & 1 & 0.006 & 100.000 & 0.000 & 0.006 & 11.074 & 88.926 \\
\hline
\end{tabular}


Table A1. Variance decompositions. (Continued)

\begin{tabular}{|c|c|c|c|c|c|c|c|}
\hline \multirow[b]{2}{*}{ Country } & \multirow[b]{2}{*}{ Period } & \multicolumn{3}{|c|}{ FUTURES } & \multicolumn{3}{|c|}{ RGDPC } \\
\hline & & S.E. & $\begin{array}{c}\varepsilon_{1 \mathrm{t}} \\
\text { (FUTURES) }\end{array}$ & $\begin{array}{c}\varepsilon_{2 t} \\
\text { (RGDPC) }\end{array}$ & S.E. & $\begin{array}{c}\varepsilon_{1 \mathrm{t}} \\
\text { (FUTURES) }\end{array}$ & $\begin{array}{c}\varepsilon_{2 t} \\
\text { (RGDPC) }\end{array}$ \\
\hline & 2 & 0.007 & 99.980 & 0.020 & 0.011 & 15.079 & 84.921 \\
\hline & 11 & 0.014 & 95.324 & 4.676 & 0.039 & 71.593 & 28.407 \\
\hline & 12 & 0.014 & 95.335 & 4.665 & 0.044 & 75.324 & 24.676 \\
\hline \multirow[t]{4}{*}{ India } & 1 & 0.121 & 100.000 & 0.000 & 0.011 & 15.457 & 84.543 \\
\hline & 2 & 0.174 & 96.759 & 3.241 & 0.016 & 8.411 & 91.589 \\
\hline & 11 & 0.311 & 87.423 & 12.577 & 0.041 & 13.530 & 86.470 \\
\hline & 12 & 0.317 & 87.468 & 12.532 & 0.043 & 13.448 & 86.552 \\
\hline \multirow[t]{4}{*}{ Italy } & 1 & 0.039 & 100.000 & 0.000 & 0.004 & 0.265 & 99.735 \\
\hline & 2 & 0.060 & 63.172 & 36.828 & 0.007 & 15.405 & 84.595 \\
\hline & 11 & 0.112 & 55.651 & 44.349 & 0.020 & 20.968 & 79.033 \\
\hline & 12 & 0.126 & 54.754 & 45.246 & 0.020 & 21.676 & 78.324 \\
\hline \multirow[t]{4}{*}{ Japan } & 1 & 0.0959 & 100.000 & 0.000 & 0.011 & 0.001 & 99.999 \\
\hline & 2 & 0.122 & 96.223 & 3.777 & 0.017 & 0.103 & 99.897 \\
\hline & 11 & 0.201 & 59.954 & 40.046 & 0.036 & 0.042 & 0.402 \\
\hline & 12 & 0.207 & 56.836 & 43.164 & 0.036 & 0.044 & 0.418 \\
\hline \multirow[t]{4}{*}{ Korea, Rep. } & 1 & 0.633 & 100.000 & 0.000 & 0.009 & 4.942 & 95.058 \\
\hline & 2 & 0.857 & 99.960 & 0.040 & 0.014 & 3.173 & 96.827 \\
\hline & 11 & 2.254 & 99.206 & 0.794 & 0.028 & 3.773 & 96.227 \\
\hline & 12 & 2.379 & 99.161 & 0.839 & 0.029 & 3.968 & 96.032 \\
\hline \multirow[t]{4}{*}{ Malaysia } & 1 & 0.000 & 100.000 & 0.000 & 0.006 & 3.035 & 96.965 \\
\hline & 2 & 0.000 & 99.995 & 0.005 & 0.007 & 21.657 & 78.343 \\
\hline & 11 & 0.000 & 99.949 & 0.051 & 0.018 & 44.788 & 55.212 \\
\hline & 12 & 0.000 & 99.944 & 0.056 & 0.018 & 45.121 & 54.879 \\
\hline \multirow[t]{4}{*}{ Mexico } & 1 & 0.002 & 100.000 & 0.000 & 0.008 & 0.006 & 99.994 \\
\hline & 2 & 0.003 & 95.403 & 4.597 & 0.015 & 0.452 & 99.548 \\
\hline & 11 & 0.008 & 92.447 & 7.553 & 0.038 & 19.922 & 80.078 \\
\hline & 12 & 0.009 & 91.975 & 8.025 & 0.039 & 21.197 & 78.803 \\
\hline \multirow[t]{4}{*}{ The Netherlands } & 1 & 0.173 & 100.000 & 0.000 & 0.005 & 2.568 & 97.432 \\
\hline & 2 & 0.234 & 95.477 & 4.523 & 0.008 & 32.213 & 67.787 \\
\hline & 11 & 0.729 & 98.397 & 1.603 & 0.040 & 94.218 & 5.782 \\
\hline & 12 & 0.744 & 98.460 & 1.540 & 0.042 & 94.622 & 5.378 \\
\hline \multirow[t]{4}{*}{ Norway } & 1 & 0.012 & 100.000 & 0.000 & 0.009 & 0.008 & 99.992 \\
\hline & 2 & 0.015 & 99.272 & 0.728 & 0.011 & 0.404 & 99.596 \\
\hline & 11 & 0.027 & 91.927 & 8.073 & 0.026 & 47.525 & 52.475 \\
\hline & 12 & 0.028 & 92.008 & 7.992 & 0.029 & 54.185 & 45.815 \\
\hline \multirow[t]{4}{*}{ Poland } & 1 & 0.000 & 100.000 & 0.000 & 0.004 & 66.742 & 33.258 \\
\hline & 2 & 0.000 & 93.597 & 6.403 & 0.007 & 76.499 & 23.501 \\
\hline & 11 & 0.004 & 75.054 & 24.946 & 0.028 & 78.563 & 21.437 \\
\hline & 12 & 0.006 & 76.605 & 23.395 & 0.028 & 78.062 & 21.938 \\
\hline \multirow[t]{4}{*}{ Portugal } & 1 & 0.003 & 100.000 & 0.000 & 0.008 & 2.444 & 97.556 \\
\hline & 2 & 0.004 & 93.239 & 6.761 & 0.013 & 3.786 & 96.214 \\
\hline & 11 & 0.005 & 69.871 & 30.129 & 0.035 & 8.208 & 91.792 \\
\hline & 12 & 0.005 & 69.309 & 30.691 & 0.036 & 8.347 & 91.653 \\
\hline \multirow[t]{4}{*}{ Russian Federation } & 1 & 2.446 & 100.000 & 0.000 & 0.005 & 32.291 & 67.709 \\
\hline & 2 & 3.307 & 99.349 & 0.651 & 0.011 & 43.196 & 56.804 \\
\hline & 11 & 6.362 & 90.948 & 9.052 & 0.032 & 73.969 & 26.031 \\
\hline & 12 & 6.403 & 89.912 & 10.088 & 0.033 & 75.991 & 24.009 \\
\hline Singapore & 1 & 0.000 & 100.000 & 0.000 & 0.020 & 1.932 & 98.068 \\
\hline
\end{tabular}


Table A1. Variance decompositions. (Continued)

\begin{tabular}{|c|c|c|c|c|c|c|c|}
\hline \multirow[b]{2}{*}{ Country } & \multirow[b]{2}{*}{ Period } & \multicolumn{3}{|c|}{ FUTURES } & \multicolumn{3}{|c|}{ RGDPC } \\
\hline & & S.E. & $\begin{array}{c}\varepsilon_{1 \mathrm{t}} \\
\text { (FUTURES) }\end{array}$ & $\begin{array}{c}\varepsilon_{2 t} \\
(R G D P C)\end{array}$ & S.E. & $\begin{array}{c}\varepsilon_{1 \mathrm{t}} \\
\text { (FUTURES) }\end{array}$ & $\begin{array}{c}\varepsilon_{2 t} \\
\text { (RGDPC) }\end{array}$ \\
\hline & 2 & 0.000 & 92.395 & 7.605 & 0.030 & 0.971 & 99.029 \\
\hline & 11 & 0.000 & 86.113 & 13.887 & 0.077 & 35.111 & 64.889 \\
\hline & 12 & 0.000 & 85.598 & 14.402 & 0.080 & 35.670 & 64.330 \\
\hline \multirow[t]{4}{*}{ South Africa } & 1 & 0.158 & 100.000 & 0.000 & 0.005 & 6.918 & 93.082 \\
\hline & 2 & 0.201 & 99.880 & 0.120 & 0.010 & 9.657 & 90.343 \\
\hline & 11 & 0.374 & 63.644 & 36.356 & 0.044 & 10.897 & 89.103 \\
\hline & 12 & 0.383 & 60.750 & 39.250 & 0.047 & 10.163 & 89.837 \\
\hline \multirow[t]{4}{*}{ Spain } & 1 & 0.118 & 100.000 & 0.000 & 0.002 & 13.332 & 86.668 \\
\hline & 2 & 0.163 & 99.018 & 0.982 & 0.005 & 15.035 & 84.965 \\
\hline & 11 & 0.407 & 80.451 & 19.549 & 0.031 & 26.398 & 73.602 \\
\hline & 12 & 0.421 & 81.083 & 18.917 & 0.032 & 26.549 & 73.451 \\
\hline \multirow[t]{4}{*}{ Sweden } & 1 & 0.040 & 100.000 & 0.000 & 0.010 & 39.491 & 60.509 \\
\hline & 2 & 0.055 & 87.570 & 12.430 & 0.016 & 58.341 & 41.659 \\
\hline & 11 & 0.206 & 56.809 & 43.191 & 0.041 & 58.383 & 41.617 \\
\hline & 12 & 0.207 & 56.867 & 43.133 & 0.041 & 58.379 & 41.621 \\
\hline \multirow[t]{4}{*}{ Switzerland } & 1 & 0.213 & 100.000 & 0.000 & 0.005 & 1.085 & 98.915 \\
\hline & 2 & 0.246 & 98.292 & 1.708 & 0.010 & 3.032 & 96.968 \\
\hline & 11 & 0.420 & 89.094 & 10.906 & 0.033 & 7.962 & 92.038 \\
\hline & 12 & 0.429 & 88.396 & 11.604 & 0.035 & 8.384 & 91.616 \\
\hline \multirow[t]{4}{*}{ Thailand } & 1 & 0.000 & 100.000 & 0.000 & 0.039 & 24.965 & 75.035 \\
\hline & 2 & 0.000 & 73.448 & 26.553 & 0.043 & 21.983 & 78.017 \\
\hline & 11 & 0.001 & 55.369 & 44.631 & 0.110 & 61.328 & 38.672 \\
\hline & 12 & 0.001 & 85.438 & 14.562 & 0.193 & 83.204 & 16.796 \\
\hline \multirow[t]{4}{*}{ Turkey } & 1 & 0.030 & 100.000 & 0.000 & 0.027 & 2.930 & 97.070 \\
\hline & 2 & 0.047 & 55.884 & 44.116 & 0.047 & 9.787 & 90.213 \\
\hline & 11 & 0.109 & 33.473 & 66.527 & 0.067 & 20.155 & 79.845 \\
\hline & 12 & 0.109 & 32.977 & 67.023 & 0.067 & 20.103 & 79.897 \\
\hline \multirow[t]{4}{*}{ United Kingdom } & 1 & 0.102 & 100.000 & 0.000 & 0.004 & 2.038 & 97.962 \\
\hline & 2 & 0.111 & 99.732 & 0.268 & 0.008 & 0.976 & 99.024 \\
\hline & 11 & 0.151 & 86.371 & 13.629 & 0.040 & 32.585 & 67.415 \\
\hline & 12 & 0.152 & 86.495 & 13.505 & 0.043 & 34.632 & 65.368 \\
\hline \multirow[t]{4}{*}{ United States } & 1 & 0.057 & 100.000 & 0.000 & 0.006 & 2.682 & 97.317 \\
\hline & 2 & 0.079 & 99.992 & 0.008 & 0.010 & 5.158 & 94.842 \\
\hline & 11 & 0.165 & 99.974 & 0.027 & 0.027 & 8.284 & 91.716 \\
\hline & 12 & 0.170 & 99.964 & 0.036 & 0.028 & 8.340 & 91.600 \\
\hline
\end{tabular}

Notes: First 2 and last 2 periods are reported to save space. Variance decomposition breaks down the variance of the forecast error for each variable into components that can be attributed to each of the endogenous variables. S.E. is the forecast error. 
Table A2. Residual serial correlation LM tests.

\begin{tabular}{|c|c|c|c|c|c|c|c|}
\hline Country & Lags & LM statistics & $p$-value & Country & Lags & LM statistics & $p$-Value \\
\hline \multirow[t]{4}{*}{ Australia } & 1 & 1.795 & 0.773 & \multirow[t]{4}{*}{ Malaysia } & 1 & 3.733 & 0.443 \\
\hline & 2 & 5.395 & 0.249 & & 2 & 3.954 & 0.412 \\
\hline & 7 & 2.189 & 0.701 & & 7 & 1.853 & 0.763 \\
\hline & 8 & 1.327 & 0.857 & & 8 & 3.684 & 0.451 \\
\hline \multirow[t]{4}{*}{ Austria } & 1 & 1.116 & 0.892 & \multirow[t]{4}{*}{ Mexico } & 1 & 5.784 & 0.216 \\
\hline & 2 & 1.506 & 0.826 & & 2 & 4.936 & 0.294 \\
\hline & 7 & 2.590 & 0.629 & & 7 & 5.250 & 0.263 \\
\hline & 8 & 1.041 & 0.904 & & 8 & 0.630 & 0.960 \\
\hline \multirow[t]{4}{*}{ Belgium } & 1 & 5.542 & 0.236 & \multirow[t]{4}{*}{ The Netherlands } & 1 & 0.721 & 0.949 \\
\hline & 2 & 2.881 & 0.578 & & 2 & 3.716 & 0.446 \\
\hline & 7 & 5.429 & 0.246 & & 7 & 5.185 & 0.269 \\
\hline & 8 & 4.636 & 0.327 & & 8 & 1.438 & 0.838 \\
\hline \multirow[t]{4}{*}{ Brazil } & 1 & 2.692 & 0.611 & \multirow[t]{4}{*}{ Norway } & 1 & 5.590 & 0.232 \\
\hline & 2 & 3.585 & 0.465 & & 2 & 5.842 & 0.211 \\
\hline & 7 & 2.333 & 0.675 & & 7 & 4.912 & 0.297 \\
\hline & 8 & 1.165 & 0.884 & & 8 & 2.978 & 0.562 \\
\hline \multirow[t]{4}{*}{ Canada } & 1 & 1.276 & 0.865 & \multirow[t]{4}{*}{ Poland } & 1 & 1.857 & 0.762 \\
\hline & 2 & 0.116 & 0.998 & & 2 & 4.726 & 0.317 \\
\hline & 7 & 2.663 & 0.616 & & 7 & 5.057 & 0.282 \\
\hline & 8 & 1.293 & 0.863 & & 8 & 1.555 & 0.817 \\
\hline \multirow[t]{4}{*}{ China } & 1 & 1.397 & 0.845 & \multirow[t]{4}{*}{ Portugal } & 1 & 5.994 & 0.200 \\
\hline & 2 & 4.963 & 0.291 & & 2 & 1.241 & 0.871 \\
\hline & 7 & 7.012 & 0.135 & & 7 & 5.350 & 0.253 \\
\hline & 8 & 6.703 & 0.152 & & 8 & 4.804 & 0.308 \\
\hline \multirow[t]{4}{*}{ Denmark } & 1 & 5.048 & 0.282 & \multirow[t]{4}{*}{ Russian Federation } & 1 & 0.907 & 0.924 \\
\hline & 2 & 5.571 & 0.234 & & 2 & 3.518 & 0.475 \\
\hline & 7 & 1.246 & 0.871 & & 7 & 1.118 & 0.891 \\
\hline & 8 & 1.651 & 0.800 & & 8 & 3.129 & 0.537 \\
\hline \multirow[t]{4}{*}{ France } & 1 & 2.592 & 0.628 & \multirow[t]{4}{*}{ Singapore } & 1 & 3.232 & 0.520 \\
\hline & 2 & 5.027 & 0.285 & & 2 & 3.572 & 0.467 \\
\hline & 7 & 5.140 & 0.273 & & 7 & 3.971 & 0.410 \\
\hline & 8 & 0.529 & 0.971 & & 8 & 1.614 & 0.806 \\
\hline \multirow[t]{4}{*}{ Germany } & 1 & 3.395 & 0.494 & \multirow[t]{4}{*}{ South Africa } & 1 & 5.359 & 0.252 \\
\hline & 2 & 2.723 & 0.605 & & 2 & 6.636 & 0.156 \\
\hline & 7 & 0.425 & 0.980 & & 7 & 4.067 & 0.397 \\
\hline & 8 & 0.809 & 0.937 & & 8 & 1.121 & 0.891 \\
\hline \multirow[t]{4}{*}{ Greece } & 1 & 1.910 & 0.752 & \multirow[t]{4}{*}{ Spain } & 1 & 6.333 & 0.176 \\
\hline & 2 & 1.816 & 0.770 & & 2 & 6.328 & 0.176 \\
\hline & 7 & 4.375 & 0.358 & & 7 & 1.478 & 0.831 \\
\hline & 8 & 2.145 & 0.709 & & 8 & 3.663 & 0.454 \\
\hline Hong Kong, China & 1 & 1.612 & 0.807 & Sweden & 1 & 4.357 & 0.360 \\
\hline & 2 & 0.553 & 0.968 & & 2 & 2.477 & 0.649 \\
\hline & 7 & 4.248 & 0.373 & & 7 & 6.148 & 0.188 \\
\hline & 8 & 6.196 & 0.185 & & 8 & 5.057 & 0.282 \\
\hline Hungary & 1 & 5.831 & 0.212 & Switzerland & 1 & 7.441 & 0.114 \\
\hline & 2 & 1.621 & 0.805 & & 2 & 1.979 & 0.740 \\
\hline & 7 & 2.201 & 0.699 & & 7 & 4.922 & 0.295 \\
\hline & 8 & 6.498 & 0.165 & & 8 & 4.664 & 0.324 \\
\hline India & 1 & 1.655 & 0.799 & Thailand & 1 & 4.154 & 0.386 \\
\hline & 2 & 7.412 & 0.116 & & 2 & 2.985 & 0.560 \\
\hline
\end{tabular}


Table A2. Residual serial correlation LM tests. (Continued)

\begin{tabular}{lccccccc}
\hline Country & Lags & LM statistics & $\boldsymbol{p}$-value & Country & Lags & LM statistics & $\boldsymbol{p}$-Value \\
\hline \multirow{4}{*}{ Italy } & 7 & 2.059 & 0.725 & & 7 & 3.823 & 0.431 \\
& 8 & 2.122 & 0.713 & & 8 & 2.397 & 0.663 \\
& 1 & 3.000 & 0.558 & Turkey & 1 & 5.475 & 0.242 \\
& 2 & 5.918 & 0.205 & & 2 & 4.079 & 0.395 \\
Japan & 7 & 0.603 & 0.963 & & 7 & 1.769 & 0.778 \\
& 8 & 2.696 & 0.610 & & 8 & 5.069 & 0.280 \\
& 1 & 1.117 & 0.892 & United Kingdom & 1 & 6.017 & 0.198 \\
& 2 & 4.256 & 0.373 & & 2 & 2.400 & 0.663 \\
Korea, Rep. & 7 & 1.378 & 0.848 & & 7 & 3.614 & 0.461 \\
& 8 & 7.030 & 0.134 & & 8 & 3.621 & 0.460 \\
& 1 & 1.379 & 0.848 & United States & 1 & 2.980 & 0.561 \\
& 2 & 2.487 & 0.647 & & 2 & 4.773 & 0.311 \\
& 7 & 1.234 & 0.873 & & 7 & 1.683 & 0.794 \\
& 8 & 0.647 & 0.958 & & 8 & 4.246 & 0.374
\end{tabular}

Notes: First 2 and last 2 lags are reported to save space. $p$-values from chi-square with 4 df. 